\title{
SOLUTION SYNTHESIS AND CHARACTERIZATION OF LITHIUM MANGANESE OXIDE CATHODE MATERIALS
}

\author{
J. A. VOIGT, T. J. BOYLE, D. H. DOUGHTY, B. A. HERNANDEZ, B. J. JOHNSON, S. C. \\ LEVY, C. J. TAFOYA, AND M. ROSAY \\ Sandia National Laboratories, P. O. Box 5800, Albuquerque, NM 87185
}

\begin{abstract}
A nonaqueous coprecipitation process has been developed to prepare controlled stoichiometry lithium manganese oxalate precipitates. The process involved mixing a methanolic Li-Mn nitrate solution with a methanolic solution containing tetramethylammonium oxalate as the precipitating agent. The resulting oxalates were readily converted to a variety of phase pure lithium manganese oxides at moderate temperatures $\left(\leq 600^{\circ} \mathrm{C}\right)$, where the phase formed was determined by the initial $\mathrm{Li} / \mathrm{Mn}$ ratio in the starting solution. Metal cation dopants have been incorporated into the oxalate precipitate by dissolving the appropriate metal nitrate in the Li-Mn precursor solution The various starting solutions, oxalate precipitates, and calcined oxides have been extensively characterized using a variety of techniques, including ${ }^{7} \mathrm{Li} \mathrm{NMR}$, TGANDTA, SEM, and XRD. Results indicate that a strong interaction occurs between $\mathrm{Li}$ and $\mathrm{Mn}$ in the nitrate solution which carries over into the oxalate phase during precipitation. The morphology and the crystallite size of the oxide powders were shown to be controlled by the morphology of the oxalate precursor and the oxalate calcination temperature, respectively. The results of initial cathode performance tests with respect to dopant type ( $\mathrm{Al}, \mathrm{Ni}, \mathrm{Co})$ and concentration for $\mathrm{LiMn}_{2} \mathrm{O}_{4}$ are also reported.
\end{abstract}

\section{INTRODUCTION}

The synthesis and characterization of $\mathrm{LiMn}_{2} \mathrm{O}_{4}$ powders recently have been the subject of much interest due to the potential use of $\mathrm{LiMn}_{2} \mathrm{O}_{4}$ as the cathode in the next generation of rechargeable lithium batteries. Despite the large amount of work reported, a consistent picture of how to optimize the physical and chemical properties of $\mathrm{LiMn}_{2} \mathrm{O}_{4}$ with respect to battery performance (i.e., capacity retention on cycling, maximum capacity, and high rate capabilities) has not emerged. For example, Tarascon et al. [1] have reported that the rate of decrease in capacity on cycling of $\mathrm{LiMn}_{2} \mathrm{O}_{4}$ was similar to that of $\mathrm{Ni}$ doped-LiMn2 $\mathrm{O}_{4}$. This is in contrast to the results of Bito and coworkers [2] who reported a much improved retention in capacity on cycling for $\mathrm{LiMn}_{2} \mathrm{O}_{4}$ when nickel was added. This example illustrates the inconsistency in results that commonly is found in the literature with respect to the performance of $\mathrm{LiMn}_{2} \mathrm{O}_{4}$. Unraveling such inconsistencies requires that the effects of physical ( $\mathrm{LiMn}_{2} \mathrm{O}_{4}$ powder properties) and chemical properties of both pure and doped-LiMn2 $\mathrm{O}_{4}$ on battery performance be separated.

We have developed a chemical synthesis process in which the powder properties of lithium manganese oxides, such as particle size, particle morphology, and surface area, can be controlled along with the homogeneous incorporation of cation dopants, as part of a program to address these issues. In this paper, we describe the synthesis procedure along with initial battery test results comparing the effects of $\mathrm{Al}, \mathrm{Co}$, and $\mathrm{Ni}$ dopants to those of undoped $\mathrm{LiMn}_{2} \mathrm{O}_{4}$. Results from this and future work will be used in conjunction with an atomistic modeling study focused on correlating doping effects to the intrinsic structure-property relationships of $\mathrm{LiMn}_{2} \mathrm{O}_{4}$ [3].

This work performed at Sandia National Laboratories, supported by the U. S. Department of Energy, Basic Energy Sciences, Chemical Sciences program under contract number DE-AC04-94AL85000. 


\section{DISCLAIMER}

This report was prepared as an account of work sponsored by an agency of the United States Government. Neither the United States Government nor any agency thereof, nor any of their employees, make any warranty, express or implied, or assumes any legal liability or responsibility for the accuracy, completeness, or usefulness of any information, apparatus, product, or process disclosed, or represents that its use would not infringe privately owned rights. Reference herein to any specific commercial product, process, or service by trade name, trademark, manufacturer, or otherwise does not necessarily constitute or imply its endorsement, recommendation, or favoring by the United States Government or any agency thereof. The views and opinions of authors expressed herein do not necessarily state or reflect those of the United States Government or any agency thereof. 


\section{DISCLAIMER}

Portions of this document may be illegible in electronic image products. Images are produced from the best available original document. 


\section{EXPERIMENTAL AND PROCESS DESCRIPTION}

The strategy we chose in developing a synthesis procedure was to use solution chemistry to prepare a crystalline precipitate with the Li-Mn stoichiometry being that of the desired oxide phase. The crystallite particle size of the oxide can then be controlled by the precipitate decomposition temperature, while the morphology and size of the oxide agglomerates can be controlled by the nucleation and growth kinetics of the crystalline precursor. The processing scheme we developed to meet these objectives is given below in Reactions 1 through 3 (illustrated for the preparation of the $\mathrm{LiMn}_{2} \mathrm{O} 4$ phase).

$$
\mathrm{LiNO}_{3}+2 \mathrm{Mn}\left(\mathrm{NO}_{3}\right)_{2} \cdot \mathrm{THF}_{0.91} \underset{5 \mathrm{~min} .}{\mathrm{MeOH}} \text { "Li-Mn2" complex }
$$

\section{$\mathrm{MeOH}$}

$$
\text { "Li-Mn2" complex }+3\left(\mathrm{~N}\left(\mathrm{CH}_{3}\right)_{4}\right)_{2} \mathrm{C}_{2} \mathrm{O}_{4} \longrightarrow \text { "LiMn2 Oxalate" coprecipitate }
$$

$$
\text { "LiMn2 Oxalate" coprecipitate } \underset{\left(600^{\circ} \mathrm{C}, 4 \mathrm{~h}\right)}{\stackrel{\text { Heat }}{\longrightarrow}} \mathrm{LiMn}_{2} \mathrm{O}_{4} \text { powder }
$$

Methanol was chosen as the solvent due to the high solubilities of the metal nitrates of interest and the corresponding insolubility of the metal species in the presence of the oxalate precipitant anions. All hydrated raw materials were carefully dehydrated to insure stoichiometric control during precipitation. For example, manganese nitrate was dehydrated using a tetrahydrofuran (THF) exchange reaction. In addition, all reactions were performed under an inert atmosphere. For the preparation of doped materials (compositions to be discussed here: $\mathrm{LiM}_{X} \mathrm{Mn}_{2-\mathrm{X}} \mathrm{O}_{4}$ where $\mathrm{M}=\mathrm{Al}, \mathrm{Co}, \mathrm{Ni}$, and $\mathrm{x}=0.125,0.250,0.375)$, the appropriate amount of dehydrated metal nitrate was added in Reaction 1.

The doped and undoped $\mathrm{LiMn}_{2} \mathrm{O}_{4}$ powders (calcined at $800^{\circ} \mathrm{C}$ ) were tested using a standard 3 - electrode battery test cell configuration. The working electrodes were 82 wt $\% \mathrm{LiM}_{\mathrm{X}} \mathrm{Mn}_{2-\mathrm{X}} \mathrm{O}_{4}$, $10 \mathrm{wt} \%$ SAB (Shawinigom Acetylene Black) carbon, and 8 wt $\%$ Teflon and had areas of 0.317 $\mathrm{cm}^{2}$. Both the reference and counter electrodes were lithium foil and a ethylene carbonate/dimethyl carbonate (EC:DMC=1:1)/1.0M LiPF6 solution was used as the electrolyte. Cells were tested galvanostatically at $0.5 \mathrm{~mA} / \mathrm{cm}^{2}$ in an argon atmosphere between potential limits of 3.5 and $4.3 \mathrm{~V}$ versus $\mathrm{Li}^{+} / \mathrm{Li}$.

\section{RESULTS AND DISCUSSION}

In the first step of the synthesis process, methanolic Li-Mn nitrate solutions were prepared with the Li:Mn ratio determined by the desired lithium manganese oxide phase to be synthesized (Reaction 1). The interaction between lithium and manganese in solution was investigated using 7 Li NMR. Figure 1 shows the NMR spectra for deuterated methanolic solutions of $\mathrm{LiNO}_{3}$ and $\mathrm{LiNO}_{3}$ plus $\mathrm{Mn}\left(\mathrm{NO}_{3}\right)_{2}$ ( $\mathrm{Li}: \mathrm{Mn}=0.5$ ). The large shift of $86 \mathrm{ppm}$ for the $\mathrm{Li} / \mathrm{Mn}$ solution and the much longer relaxation time relative to the Li solution are indications of a strong Li-Mn chemical interaction and the formation of a " $\mathrm{Li}-\mathrm{Mn}$ " complex in solution.

The mixing of the Li-Mn solution with a methanolic tetramethylammonium oxalate precipitant solution (Reaction 2) causes the instantaneous precipitation of a crystalline Li-Mn oxalate 
coprecipitate. Examples of the rod-like morphology of the precipitates prepared by this process are shown in Figure 2. The figure shows the similarity in morphologies for LiMn2 oxalate and $\mathrm{Mn}$ oxalate. Although the morphologies are similar, $\mathrm{x}$-ray diffraction results indicate that the structure of the LiMn2 oxalate differs from that of the pure Mn oxalate due to the incorporation of lithium.

Thermogravimetric analysis (TGA) and differential thermal analysis (DTA) of the oxalate coprecipitate were used to determine an appropriate thermal cycle for conversion to the oxide (Reaction 3 ). Figure 3 is an example of typical TGA/DTA data for LiMn2 oxalate powder using a constant heating rate of $5^{\circ} \mathrm{C} / \mathrm{min}$.

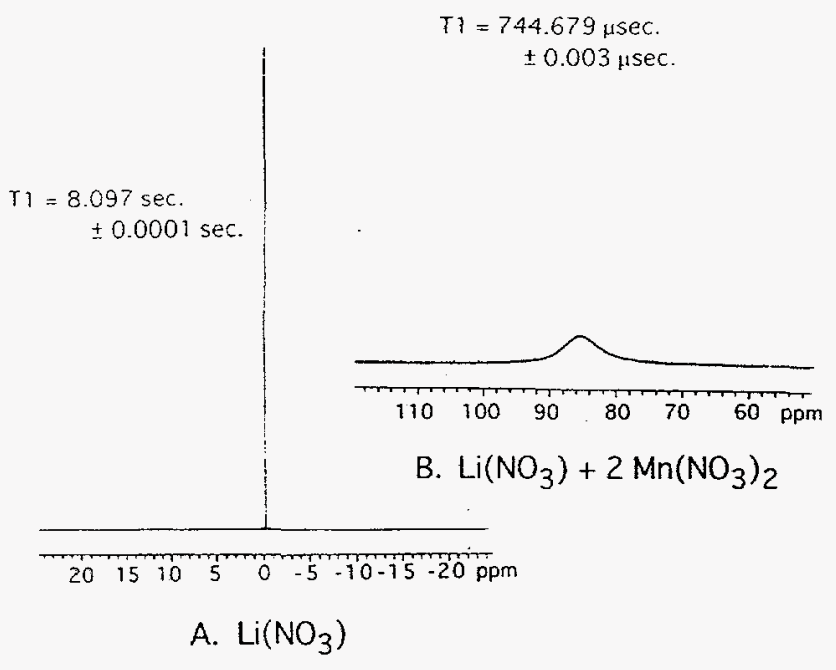

Fig 1. ${ }^{7} \mathrm{Li}$ NMR spectra of (A) $\mathrm{LiNO}_{3}$ and (B) $\mathrm{LiNO}_{3}$ plus $\mathrm{Mn}\left(\mathrm{NO}_{3}\right)_{2}(\mathrm{Li} \mathrm{Mn}=0.5)$ in $\mathrm{CD} 3 \mathrm{OD}$. The large recoalescence peak in the DTA data is an indication of the highly exothermic nature of the oxalate decomposition process. Such exothermic decomposition reactions can cause "hot spots" in the powder bed that can lead to formation of unwanted hard agglomerates. In order to minimize this effect, heating schedules with much slower heating rates in the decomposition region were used. Figure 4 shows TGA/DTA data for such a thermal cycle [heating schedule: 1) room temperature to $125^{\circ} \mathrm{C}$ at $5^{\circ} \mathrm{C} / \mathrm{min}$, 2) 125 to $150^{\circ} \mathrm{C}$ at $1^{\circ} \mathrm{C} / \mathrm{min}$, 3) 150 to $350^{\circ} \mathrm{C}$ at $0.2^{\circ} \mathrm{C} / \mathrm{min}$, 4) $350^{\circ} \mathrm{C}$ to $600^{\circ} \mathrm{C}$ at $10^{\circ} \mathrm{C} / \mathrm{min}$, and hold for 120 $\min$ at $600^{\circ} \mathrm{C}$. The figure shows, that by using the slow heating rates of steps 2 and 3 , the decomposition exotherms are very controlled (Note the difference in maximum DTA output signal of $210 \mu \mathrm{V}$ versus $11 \mu \mathrm{V}$ for the fast (Fig. 3) and slow (Fig. 4) heating rates, respectively). For the slowly heated sample, the $\mathrm{LiMn}_{2} \mathrm{O}_{4}$ crystallization exotherm is clearly seen and has an onset temperature of $304^{\circ} \mathrm{C}$.
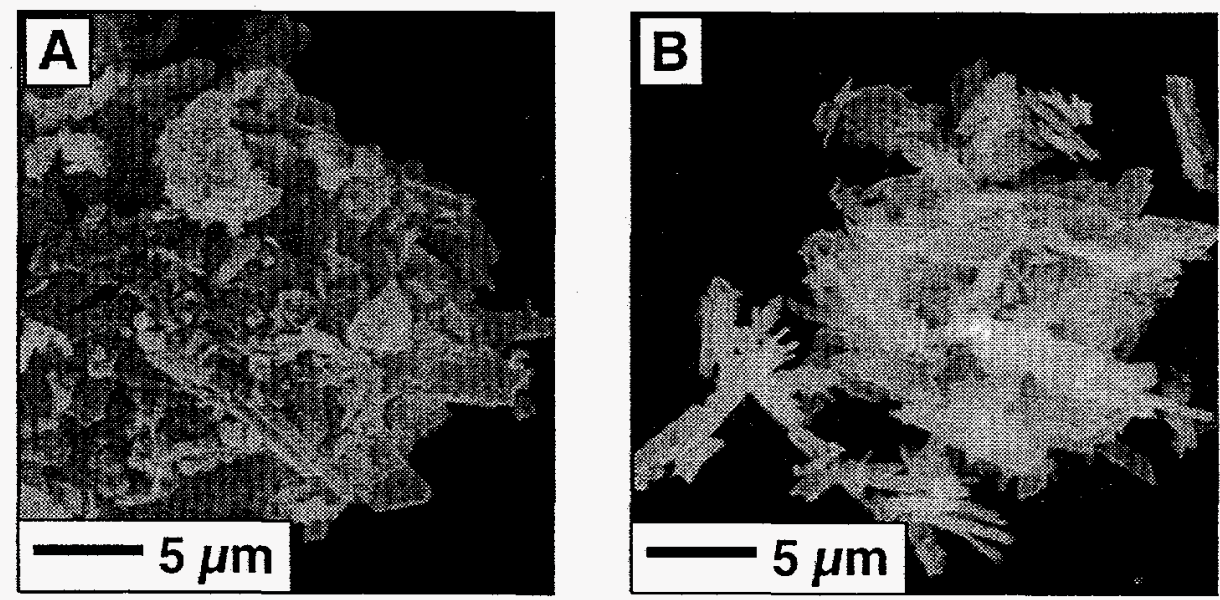

Fig 2. Scanning electron microscope (SEM) photos showing the rod-like morphology of (A) LiMn2 oxalate and (B) Mn oxalate.

One of the goals of this work was to prepare the various lithium manganese oxides in phase pure form. Figure 5 shows $x$-ray results for LiMn2 oxalate and Li3 Mn oxalate powders that were 
decomposed at $600^{\circ} \mathrm{C}$. As indicated in the figure, all diffraction lines were indexable to the expected $\mathrm{LiMn}_{2} \mathrm{O}_{4}$ and $\mathrm{Li}_{3} \mathrm{MnO}_{3}$ phases. These results indicate that phase pure lithium manganese oxides can be prepared by this process as determined by $\mathrm{x}$-ray diffraction.

Another goal was to use the morphology of the precursor oxalate as the template for the agglomerate structure of the oxide. This is indeed the case as shown by the SEM photo in Figure $6 \mathrm{~A}$ of $\mathrm{LiMn}_{2} \mathrm{O}_{4}$ which had been calcined at $600^{\circ} \mathrm{C}$. A comparison of this picture with Figure 2A shows that the rod-like morphology of the precursor oxalate is retained by the oxide. The oxide agglomerates are composed of $\approx 300$ $\AA \mathrm{LiMn}_{2} \mathrm{O}_{4}$ crystallites, as shown by Figure 6B. By heat treating the oxide at higher temperatures, the $\mathrm{LiMn}_{2} \mathrm{O}_{4}$ crystallite size can be increased. This is illustrated by the SEM photo shown in Figure 6C of a $\mathrm{LiMn}_{2} \mathrm{O}_{4}$ sample that was calcined at $800^{\circ} \mathrm{C}$. The oxide crystallite size has increased by an order of magnitude relative to the $600^{\circ} \mathrm{C}$ sample (Fig. 6B).

The other goal of this project was to have the ability to incorporate a variety of metal dopants into the oxide precursors in order to improve dopant homogeneity. For this work, we chose dopants that have been investigated by other researchers, specifically $\mathrm{Al}, \mathrm{Co}$, and $\mathrm{Ni}[1,2]$. Although we have not analyzed the doped-oxalate precipitates for the degree of dopant incorporation, lattice constant data of the calcined doped$\mathrm{LiMn}_{2} \mathrm{O}_{4}$ powders decrease with increasing dopant level. This is the expected trend as discussed by Cygan and coworkers [3].

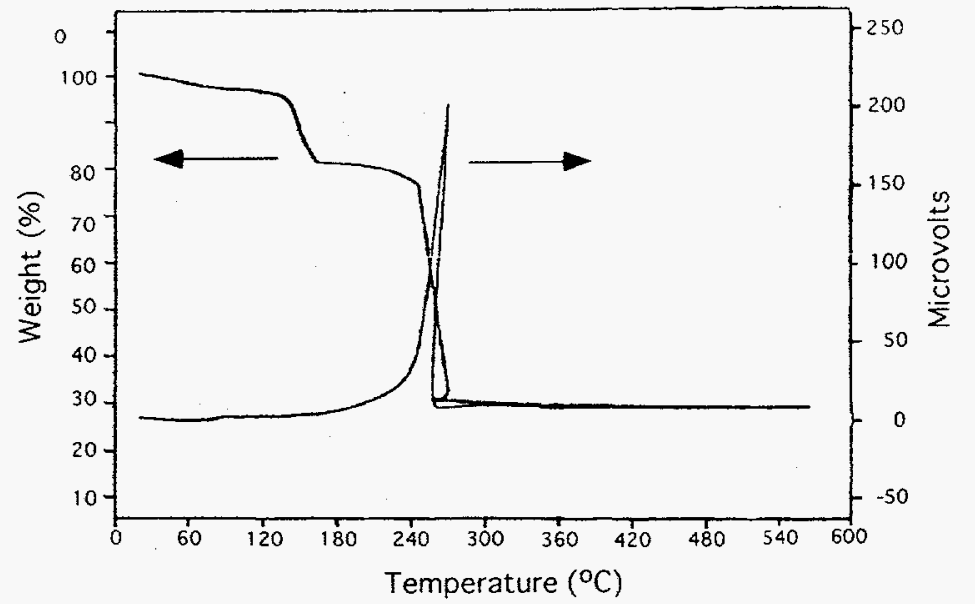

Fig 3. DTA/TGA of LiMn2 oxalate $\left(\right.$ rate $\left.=5^{\circ} \mathrm{C} / \mathrm{min}\right)$.

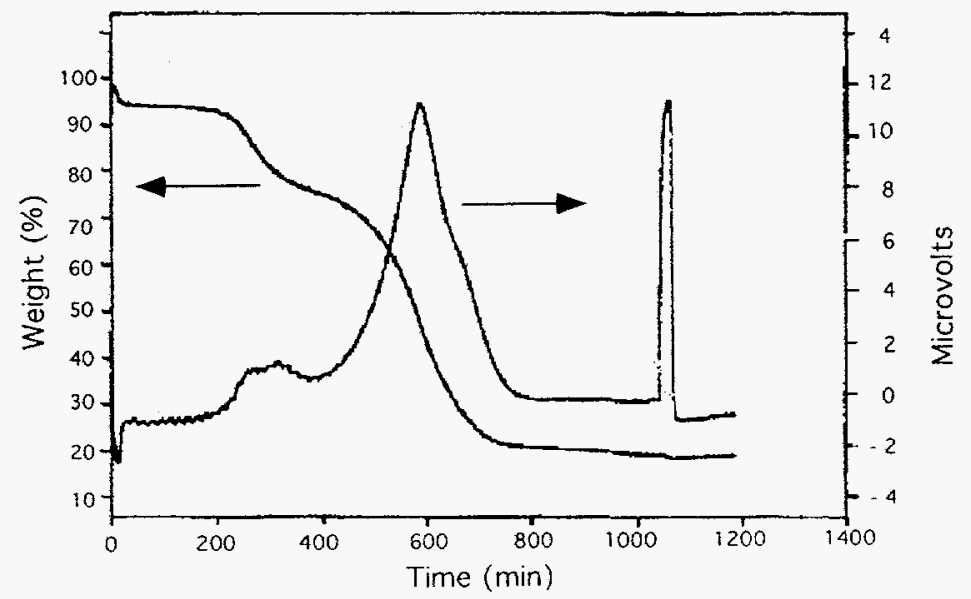

Fig 4. DTA/TGA of LiMn2 oxalate (rate $=$ see text).

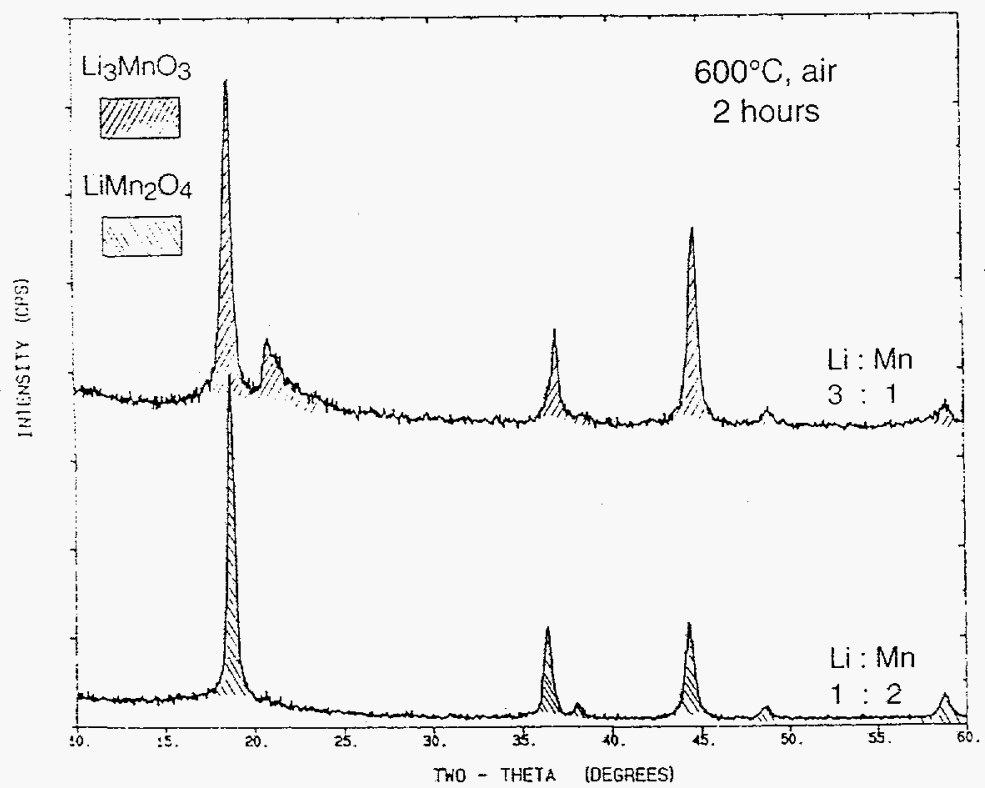

Fig 5. XRD patterns of calcined Li-Mn oxalates. 


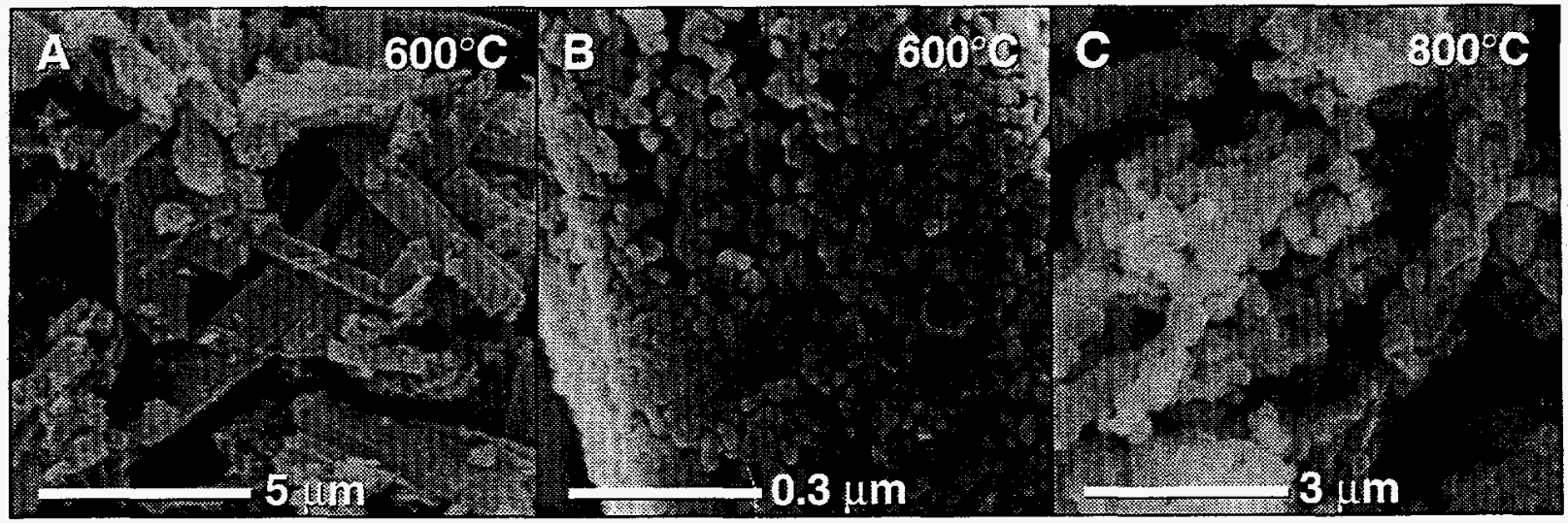

Fig 6. Scanning electron microscope (SEM) photos $\mathrm{LiMn}_{2} \mathrm{O}_{4}$ calcined at $600^{\circ} \mathrm{C}$ $(A$ and $B)$ and $800^{\circ} \mathrm{C}(\mathrm{C})$.

We have carried out initial battery test cell experiments on the undoped and doped-LiMn2 $\mathrm{O}_{4}$ powders. The cathodes were prepared using a cathode formulation and preparation process that was optimized for a commercial $\mathrm{LiMn}_{2} \mathrm{O}_{4}$ powder. Therefore, the results discussed below illustrate only general trends and not optimized capacity levels. Figure 7 compares the initial discharge capacities for the various dopants as a function of dopant level, $x$, where $\mathrm{x}$ is defined by the subscript $\mathrm{x}$ in $\mathrm{LiM}_{\mathrm{X}} \mathrm{Mn}_{2-\mathrm{x}} \mathrm{O}_{4}$. All three dopants show a decrease in capacity with increasing dopant level (with the exception of the LiCo0.250Mn $1.75 \mathrm{O}_{4}$ sample) which is consistent with the literature $[1,2]$. The reason for the decrease can be explained by assuming: (1) the dopant does not extend the $4 \mathrm{~V}$ plateau (i.e., going beyond $\approx \mathrm{LiMn}_{2} \mathrm{O}_{4}$ on discharge), (2) the dopant oxidation state is constant, and (3) the oxygen stoichiometry remains fixed. If these assumptions hold, then any +2 or +3 dopant that substitutes for $\mathrm{Mn}$ in the lattice will decrease the intrinsic capacity of $\mathrm{LiMn}_{2} \mathrm{O}_{4}$.

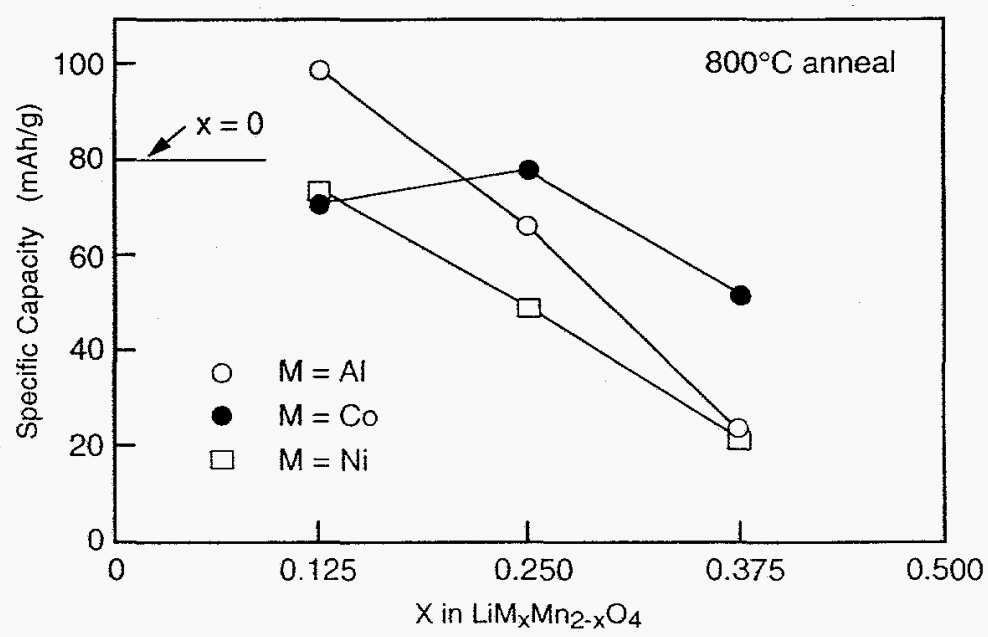

Fig 7. Initial capacity data for $\mathrm{Al}_{-}, \mathrm{Co}_{-}$, and $\mathrm{Ni}$-doped $\mathrm{LiMn}_{2} \mathrm{O}_{4}$.

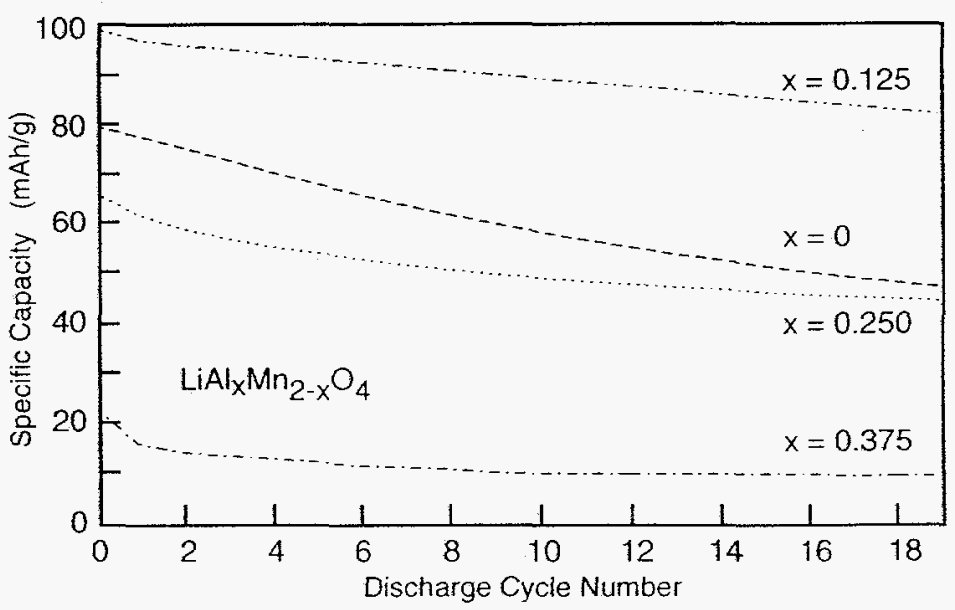

Fig 8. Capacity of $\mathrm{LiAl}_{\mathrm{X}} \mathrm{Mn}_{2-\mathrm{x}} \mathrm{O}_{4}$ as a function of cycle number. 
This can be visualized by the fact that electroneutrality must be maintained and, therefore, addition of any of these dopants will increase the average valence of Mn. As a result, the amount of Mn that remains to be oxidized to +4 during charging (i.e., the amount lithium that can be deintercalated) will decrease linearly with increasing levels of substitution. This also implies that capacity should go to zero when the dopant level is such that $\mathrm{Mn}$ is fully oxidized to +4 in the discharged state, or at $\mathrm{x}=0.5$ and $\mathrm{x}=1$ for $\mathrm{M}^{+2}$ and $\mathrm{M}^{+3}$ dopants, respectively. The data in Figure 7 is in mixed aggreement with this analysis. The Ni-substituted data is in good agreement in that capacity decreases linearly with increasing levels of substitution and it extrapolates to a capacity of $\approx 0$ at the predicted $x=0.5$ value. The trends in the Al- and Co-substituted data clearly do not agree.

Capacity data as a function of discharge cycle number is presented in Figures 8 and 9 for the $\mathrm{Al}$ - and Ni-doped samples. These results agree with Bito et al. in that the amount of fade is improved with doping relative to the undoped sample. The fact that the undoped $\mathrm{LiMn}_{2} \mathrm{O}_{4}$ is below that of the LiAlo.125Mn $1.875 \mathrm{O}_{4}$ and well below typical initial capacities indicates that further work is needed in optimizing cathode preparation for these types of powders.

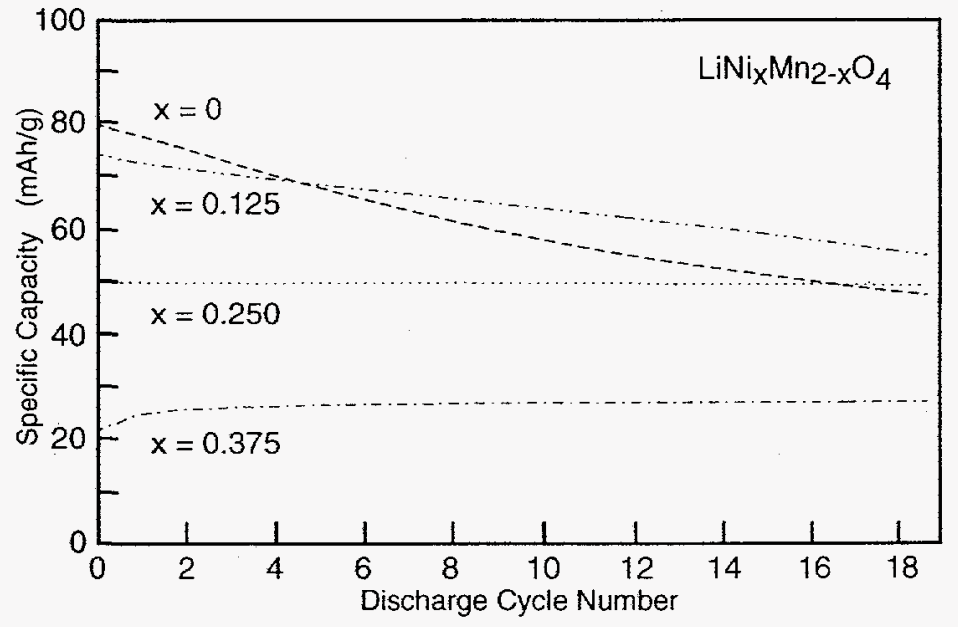

Fig 9. Capacity of $\mathrm{LiNi}_{\mathrm{X}} \mathrm{Mn}_{2}-\mathrm{XO}_{4}$ as a function of cycle number.

\section{SUMMARY}

We have described an oxalate-based chemical synthesis route to phase pure doped-lithium manganese oxides. The phases can be crystallized at low temperatures $\left(\approx 300^{\circ} \mathrm{C}\right.$ for $\left.\mathrm{LiMn}_{2} \mathrm{O}_{4}\right)$. It has been demonstrated that oxide crystallite size and morphology are controlled by the oxalate calcination temperature and the morphology of the oxalate precursor, respectively. Initial battery test results on $\mathrm{Al}-, \mathrm{Co}-$, and $\mathrm{Ni}$-doped $\mathrm{LiMn}_{2} \mathrm{O}_{4}$ showed the expected decrease in capacity with increasing dopant levels. Also, the improved resistance to fade on cycling with doped materials is consistent with previous researchers [2]. The lower than expected capacity of the doped and undoped $\mathrm{LiMn}_{2} \mathrm{O}_{4}$ powders indicates further work needs to be done on optimizing cathode formulation and processing. Finally, the inconsistencies of the different dopants with regard to the initial capacity versus dopant level indicates further physical, chemical, and electrical characterization of the powders is needed.

\section{REFERENCES}

1) J. M. Tarascon, E. Wang, F. K. Shokoohi, W. R. McKinnon and S. Colson, J. Electrochem.Soc.138, 2859 (1991).

2) Y. Bito, H. Murai, S. Ito, M. Hasegawa, and Y. Toyoguchi, ECS Proceedings Volume PV 93-23, 461 (1993).

3) R. T. Cygan, H. R. Westrich, and D. H. Doughty, this proceedings. 